Thorax (1969), 24, 729.

\title{
A reconstruction of the duct system and secretory tubules of the human bronchial submucosal gland
}

\author{
BARBARA MEYRICK, JEN IFER M. STURGESS, \\ A N D L Y N NE REID \\ From the Department of Experimental Pathology, Institute of Diseases of the Chest, Brompton Hospital, \\ London, S.W.3
}

\begin{abstract}
A graphic reconstruction has been made of a submucosal gland from a normal human main bronchus, revealing a collecting duct not previously described. Ciliated respiratory epithelium dips into the gland opening to line the first part of the duct, the ciliated duct, and then gives way, in the collecting duct, to an epithelium composed of tall, columnar, eosinophilic cells containing numerous large mitochondria. This cell structure suggests that the collecting duct controls ionic and water concentration. From the collecting duct arise secretory tubules lined by mucous cells-mucous tubules. Tubules lined by serous cells-serous tubules-arise from mucous tubules either terminally or laterally.
\end{abstract}

Submucosal glands are found in the normal human bronchial tree in those airways with cartilage in the wall. The glands lie between the epithelium and plates of cartilage and between, and occasionally external to, the plates of cartilage (Miller, 1947 ; Reid, 1968). They have been variously described as compound tubular, tubuloacinar, and racemose structures. Fuchs-Wolfring (1898) described two cell types-the mucous, and the serous or albuminous-and reported that sometimes the mucous cells were in continuity with high columnar epithelium.

Recent electron microscopic studies have revealed in the bronchial glands a cell type not previously reported at this site (Meyrick and Reid, 1969). It is filled with numerous large mitochondria (Fig. 1) and has a well-developed Golgi apparatus. Dense granules lie near the cell apex and lateral edges, and most cells include lipochondria. The plasma membrane of the base is flat and uncomplicated but the lateral surfaces interdigitate with adjacent cells. These cells are found next to mucous cells and are arranged as a tube. Myoepithelial cells are found in association with them as well as with the secretory cells.

The present paper describes an extension of this study to light microscopy, which has revealed a central duct system in the bronchial gland lined with these cells. A description is also given of a reconstruction of the duct system and of the mucous and serous secretory tubules.

\section{MATERIALS AND METHODS}

PREPARATION OF TISSUES FOR LIGHT MICROSCOPY Specimens of bronchus were obtained at neoropsy and from surgical resection. The cases studied were either 'normal' or had a history of 'simple bronchitis'. Bronchial rings were examined from 20 cases, 17 men and 3 women, with an age range from 16 to 65 years. Fifteen of the specimens were obtained at resection and five at necropsy: of the latter, one was from a woman and four were from men. Resection specimens were from patients with carcinoma save for one who suffered from bronchiectasis: these specimens included main and lobar bronchi. The necropsy lungs were considered normal: these specimens included trachea and main bronchus. In total, there were three specimens of trachea, 13 of main bronchus, and four of lobar bronchus. The specimen used for the gland reconstruction was from a man, 63 years of age, who died from a dissecting aneurysm of the aorta.

The bronchial specimens were taken within half an hour of resection, or two hours of necropsy, and fixed in buffered formol-saline for 24 hours. Specimens used for identification of mitochondria were fixed in Helly's fluid for 24 hours, followed by treatment with $4 \%$ potassium dichromate for four days. Complete rings of bronchus were dehydrated through graded alcohols, cleared in chloroform in an automatic Histokinette, and then embedded in paraffin wax $\left(56^{\circ} \mathrm{C}\right.$.) under vacuum. From all bronchial rings serial sections, $4 \mu \mathrm{m}$. thick, were cut, mounted separately and numbered consecutively. Adjacent sections were stained by various histochemical techniques in order that the staining reaction of comparable areas 


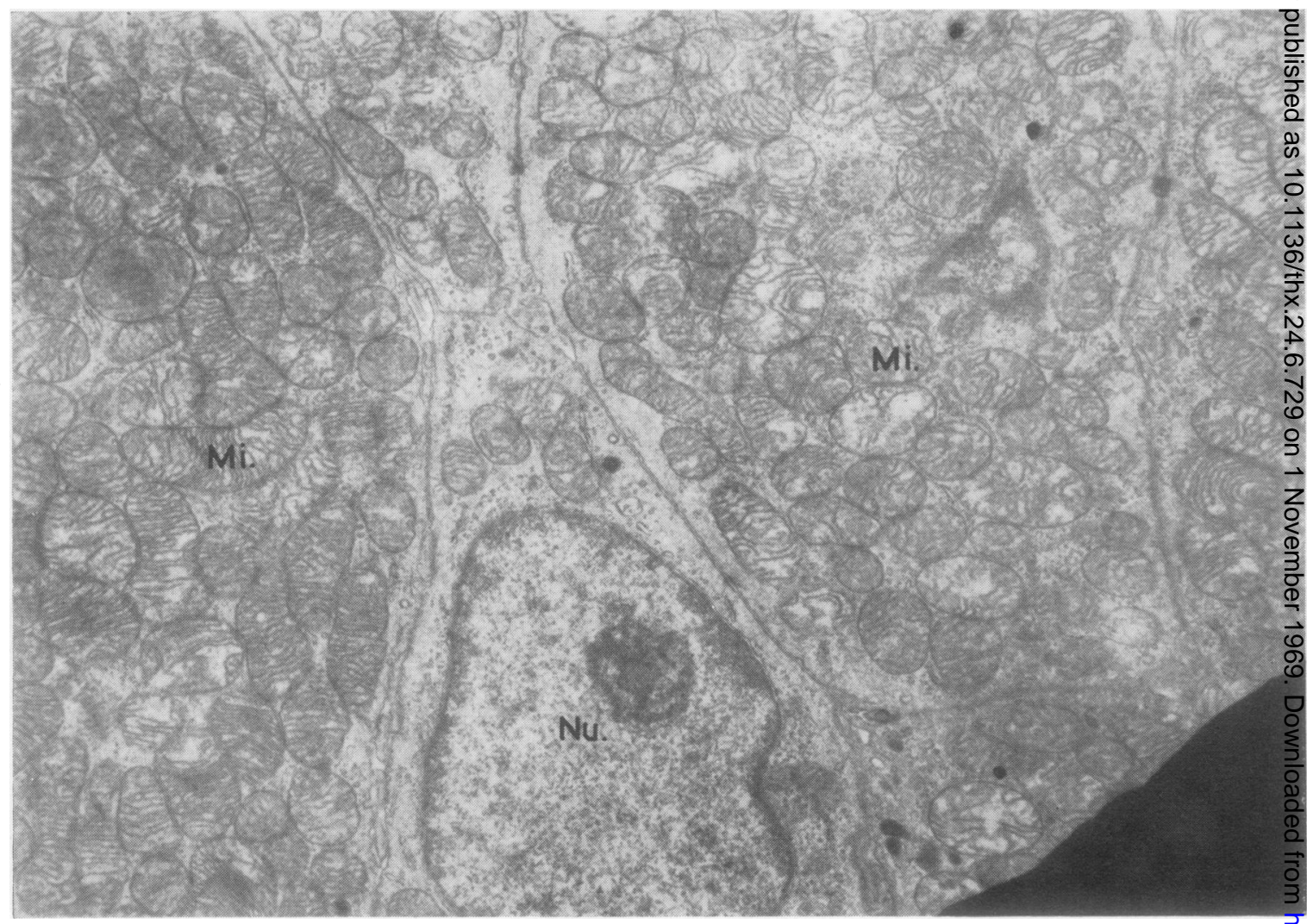

FIG. 1. Electron micrograph of part of several collecting duct cells showing densely packed mitochondria (Mi.). and nucleus (Nu.). (Glutaraldehyde and osmium tetroxide:lead hydroxide. $\times 20,800$.)

of gland could be examined. The following stains were used:

Ehrlich's haematoxylin and eosin (Culling, 1957);

Periodic acid Schiff (PAS) (Lamb, 1969 ; Lamb and Reid, 1969a);

Alcian blue/PAS (Lamb, 1969; Lamb and Reid, 1969a): and

Heidenhain's iron haematoxylin (Culling, 1957).

All tissue sections were examined microscopically using oil immersion, to establish the staining reactions of structures within the gland.

AUTORADIOGRAPHY AND ORGAN CULTURE Strips of normal bronchial mucosa were dissected from a ring of bronchus, obtained immediately after surgical resection. The pieces of mucosa, approximately $2 \times 2 \times 10$ $\mathrm{mm}$., were incubated using a modification of Trowell's (1959) technique. Tritium-labelled glucose (Radiochemical Centre, Amersham) was added to the culture fluid (TC199, Glaxo Laboratories Ltd.) to give a concentration of $10 \mu \mathrm{Ci} / \mathrm{ml}$. The tissues were incubated for four hours at $37^{\circ} \mathrm{C}$.
After incubation the tissues were fixed and pro $\frac{0}{3}$ cessed, and sections were cut as for the bronchiab rings. Autoradiographs of PAS-stained sections were prepared, using Kodak AR10, by the stripping film technique (Pelc, 1947). The autoradiographs were exposed for four days at $4^{\circ} \mathrm{C}$., developed using Kodax D19 high contrast developer, and fixed in Fix-sol (Johnsons of Hendon).

GRAPHIC RECONSTRUCTION OF GLAND A ring of humain main bronchus obtained at necropsy was used for the graphic reconstruction of a gland. A suitable area of tissue was selected by dropping Ehrlich's haematoxy? lin on to the epithelial surface of the bronchus anse then rinsing in tap water. Haematoxylin accumulateco in duct openings within a minute or so. An area of bronchial mucosa, approximately $5 \times 5 \mathrm{~mm}$. and in $=0$ cluding a duct, was dissected from a region oveō cartilage. This tissue was prepared as above anci embedded so that it could be cut in a plane paralle to the surface epithelium. The entire piece of tissue was cut serially into sections $5 \mu \mathrm{m}$. thick. The tota? 
number of sections was 184 , and represented roughly $1 \mathrm{~mm}$. of processed tissue. All sections were mounted consecutively and stained with alcian blue/periodic acid Schiff.

The slides were projected on to tracing paper on a bench with an invented microscope, a modern version of the Edinger apparatus. A scale drawing of the image was made at a magnification of 90 , and the drawings were superimposed to reconstruct graphically the main duct system and its branches.

The external diameter and lumen size of the main duct system were measured from the drawings. The length of the ducts and tubules was estimated by reference to the number of sections through which they passed and to their length in longitudinal section. Because of their tortuosity it was difficult to measure accurately the total length of the mucous tubules, but their diameter and site of origin in the series of sections were accurately determined.

\section{RESULTS}

GRAPHIC RECONSTRUCTION OF BRONCHIAL SUBMUCOSAL GLAND A study of the serial sections of a gland in a normal human bronchus revealed a collecting duct not previously described: from this duct the secretory tubules arise (Figs 2 and 3 ). Figure 2 represents a graphic reconstruction of the main duct system and its major branches. The description given here refers to this reconstruction, but the observations have been confirmed and supplemented from detailed examination of sections from the 19 other specimens. The gland is

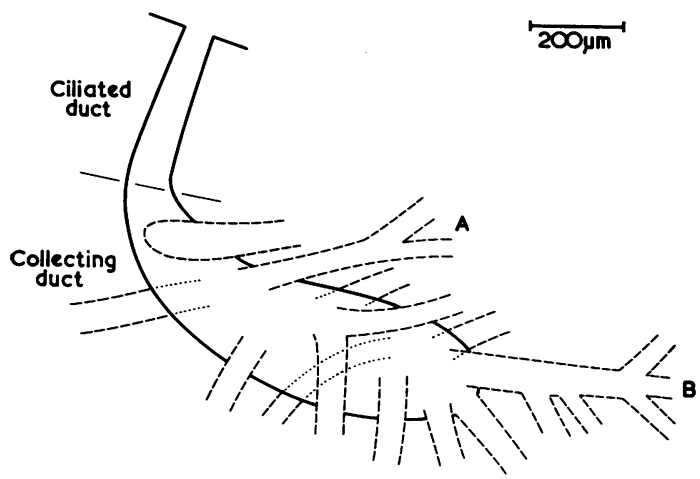

FIG. 2. Graphic reconstruction, drawn to scale, of the collecting duct and its major branches in a human bronchial gland. Lines represent the basement membranes of ducts and tubules. Thirteen major secretory tubules are shown: in addition, four rudimentary tubules (not shown) arise from the collecting duct between its origin from the ciliated duct and the first mucous tubule shown. The structure of secretory tubules $A$ and $B$ is shown in Figure 3.
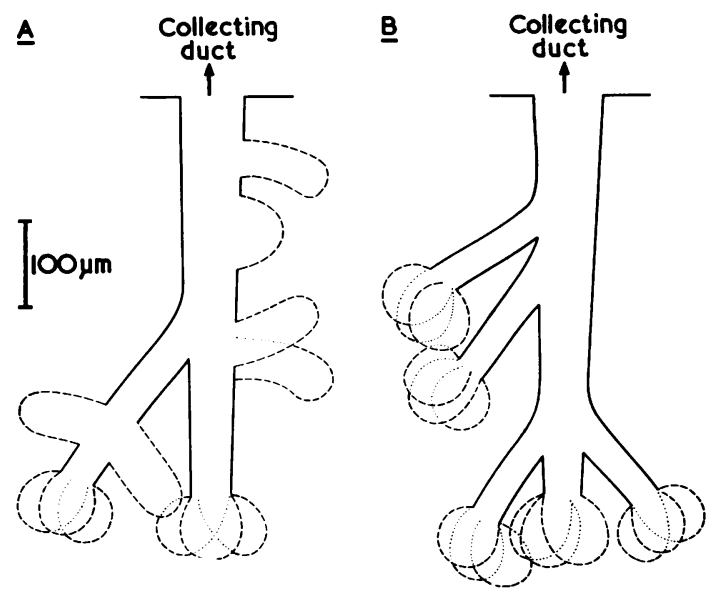

FIG. 3. Graphic reconstruction, drawn to scale, of two secretory tubules, $A$ and $B$ (Figure 2), from their junction with the collecting duct to show the distribution of serous (broken line) and mucous (continuous line) cells. A arises from the proximal part of the collecting duct, $B$ from the distal. The lines represent the basement membranes of the secretory tubules.

described from the surface epithelium, regarded as proximal, to the farthest tip of a secretory tubule, regarded as distal. This is in the reverse direction from the flow of secretion.

The first part of the main duct is lined by respiratory type epithelium, including ciliated cells, and is therefore called the 'ciliated duct' (Figs 2 and 4). This epithelium is replaced by one composed of non-ciliated cells, packed with mitochondria, called hereafter the 'collecting duct' (Fig. 4). This duct gives rise to numerous branches, the secretory tubules (Figs 2 and 5). These branch several times and are of two types, the mucous and the serous. From the gland illustrated in Fig. 2 two secretory tubules A and B were reconstructed (Fig. 3). These three regions, (1) ciliated duct, (2) collecting duct, and (3) secretory tubules, were found in all bronchial glands examined. Their dimensions are summarized in the Table.

T A B L E

DIMENSIONS $(\mu \mathrm{m}$.) OF DUCTS AND SECRETORY TUBULES IN GRAPHIC RECONSTRUCTION OF HUMAN SUBMUCOSAL GLAND FROM MAIN BRONCHUS

\begin{tabular}{|c|c|c|c|c|}
\hline & & Length & $\begin{array}{c}\text { External } \\
\text { Diameter }\end{array}$ & $\begin{array}{l}\text { Height of } \\
\text { Epithelium }\end{array}$ \\
\hline $\begin{array}{l}\text { Ciliated duct } \\
\text { Collecting duct } \\
\text { Mucous tubule } \\
\text { Serous tubule }\end{array}$ & $\begin{array}{l}\cdots \\
\cdots \\
\cdots\end{array}$ & $\begin{array}{l}350 \\
800 \\
500 \\
180\end{array}$ & $\begin{array}{l}65-90 \\
90-250 \\
50-75 \\
50-70\end{array}$ & $\begin{array}{l}20-30 \\
60-70 \\
25-30 \\
20-30\end{array}$ \\
\hline
\end{tabular}


Ciliated duct The ciliated duct leads from the surface epithelium of the bronchus into the collecting duct; it is not seen to branch. The length of the ciliated duct in the reconstructed gland is $350 \mu \mathrm{m}$., the external diameter, at the bronchial lumen, approximately $65 \mu \mathrm{m}$., widening to $90 \mu \mathrm{m}$. at its distal end. The duct epithelium is identical to and continuous with the cells of the surface epithelium and thus includes ciliated, columnar, and goblet cells. The cells are 20-30 $\mu \mathrm{m}$. high. Goblet cells are less frequent in the duct than in the surface epithelium and give a strong blue or blue-red reaction with alcian blue/ PAS and magenta with PAS.

Collecting duct The ciliated duct passes directly into a collecting duct (Figs 2 and 4) from which secretory tubules arise (Fig. 5). Occasionally the duct itself is observed to branch. From its junction with the ciliated duct the collecting duct increases in external diameter to a maximum of $250 \mu \mathrm{m}$ 웅 due to an increase in both height of the epitheliuri and lumen diameter. At its widest point the lumen has a diameter of $110 \mu \mathrm{m}$. and narrow९ towards its distal end. The length of the collectinge duct in the reconstructed gland is $800 \mu \mathrm{m}$. The end of the collecting duct leads into the last secre tory tubule (Fig. 2).

The epithelial cells of the collecting duct are tall, columnar cells with centrally placed nuclex (Fig. 4). At the proximal end of the duct they are about $30 \mu \mathrm{m}$. high and within a short distance in. crease to a maximum of $70 \mu \mathrm{m}$. The cytoplasm of these cells is strongly eosinophilic and appears granular, presumably because of the numerous mitochondria revealed by Heidenhain's stain. The cytoplasm shows no reaction with alcian blue/o PAS (Fig. 5), save for the few large granules, 1-20 $\mu \mathrm{m}$. in diameter, that are found in most of thes cells and stain with PAS.

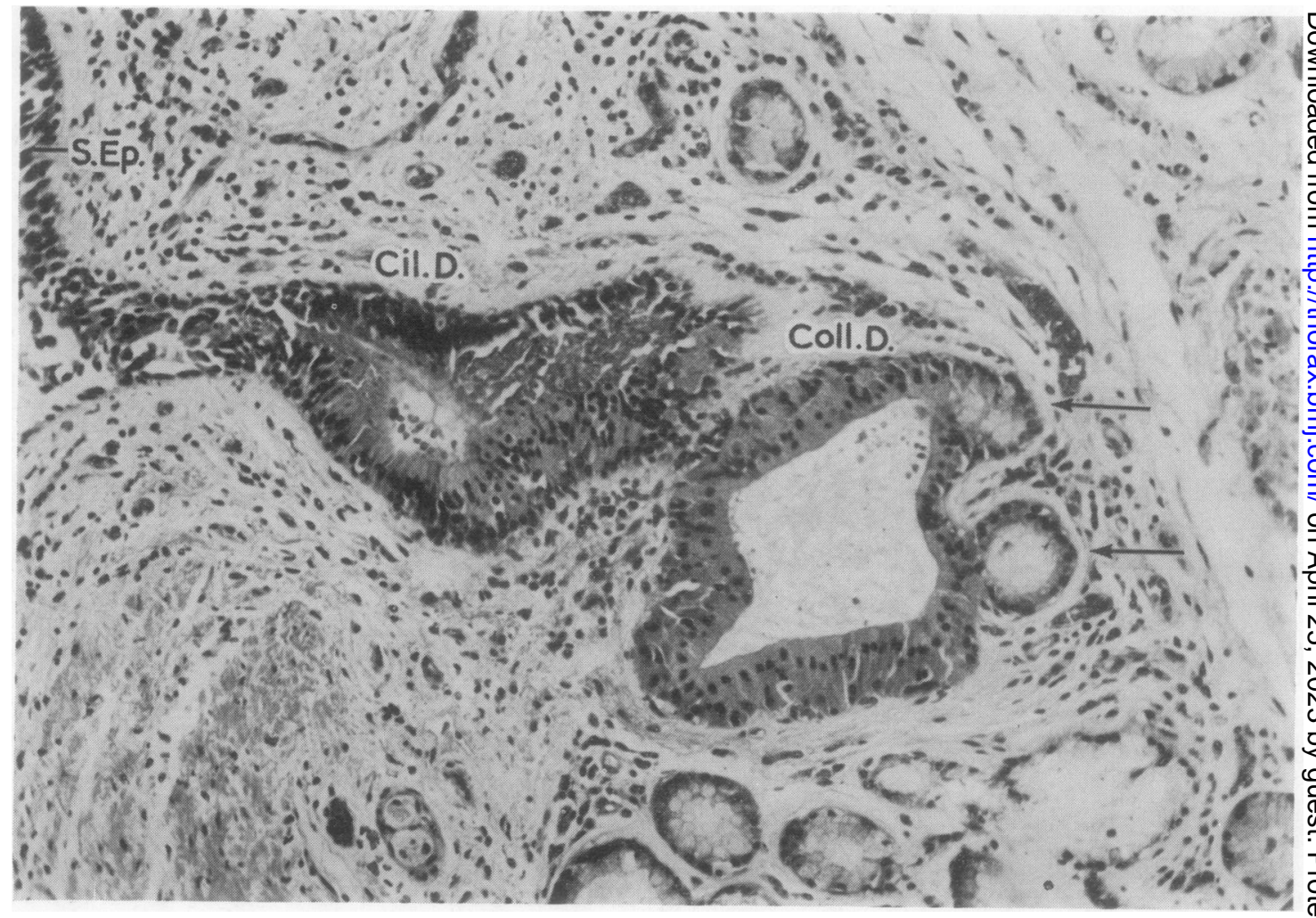

FIG. 4. Photomicrograph of the bronchial wall showing the surface epithelium (S.Ep.) and ciliated duct (Cil.D.) $\stackrel{\varrho}{\stackrel{\oplus}{(}}$ to the left, and collecting duct (Coll.D.) to the right. Two mucous tubules, each shown by ar arrow, arise from 0 the collecting duct. ( $H$ and $E$. $\times 190$.) 


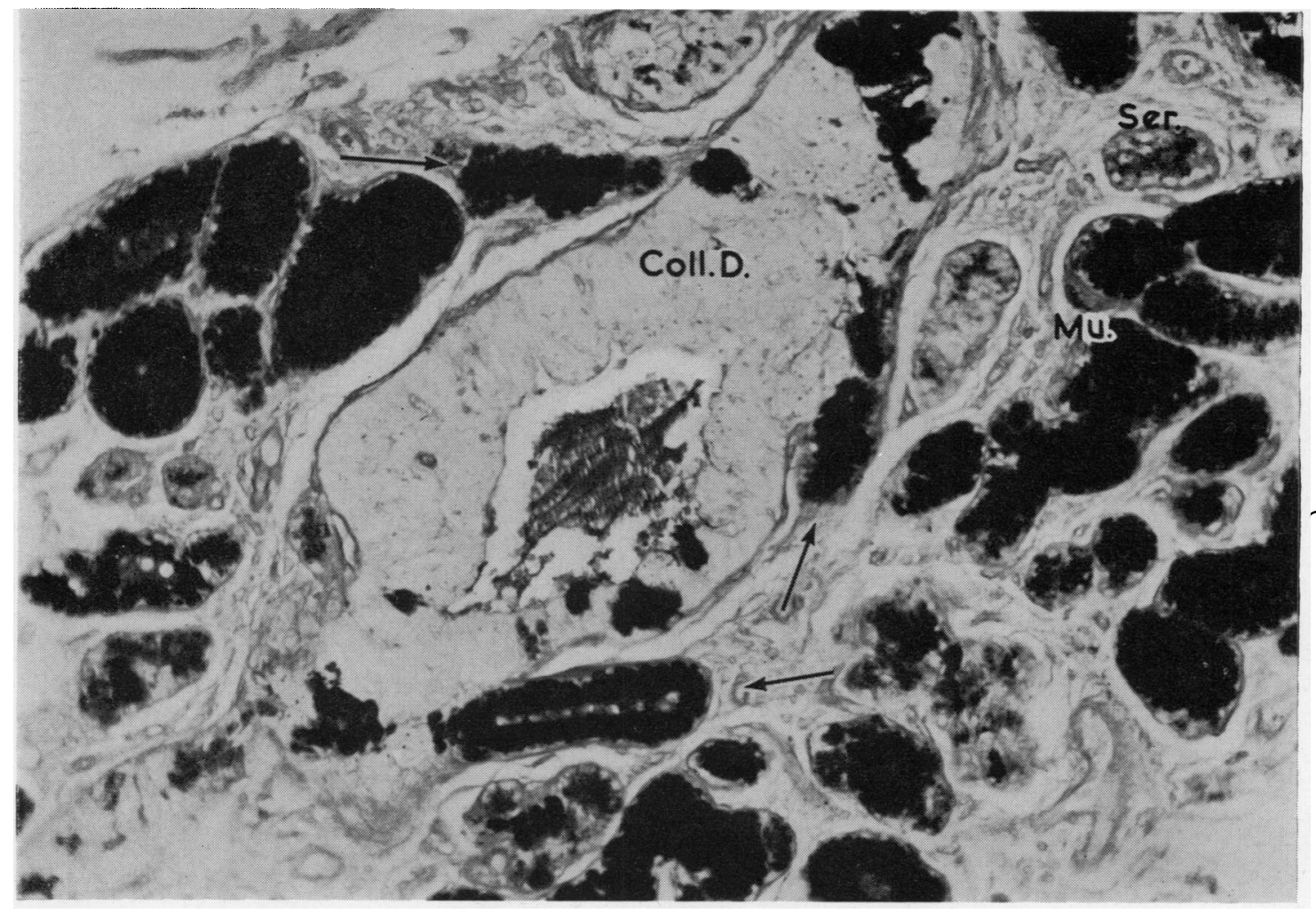

FIG. 5. Photomicrograph of the collecting duct included in the gland reconstruction in Figure 2. The collecting duct (Coll.D.) is lined by tall, columnar cells and its lumen contains mucus. Secretory tubules (shown by arrows) branch from the collecting duct. Mucous (Mu.) and serous (Ser.) tubules are seen in cross-section. (Alcian blue/PAS. $\times$ 190.)

Alcian blue/PAS demonstrates mucus in the duct lumen.

Autoradiographic studies show that tritiumlabelled glucose is readily incorporated into the cells of the collecting duct. Silver grains are found to lie evenly over the cytoplasm and are not restricted to any region of the cell, nor can they be localized over organelles.

The transition from the epithelium of the ciliated to that of the collecting duct is abrupt. The junctions between the collecting duct and the secretory tubules also show an abrupt change of epithelium to one composed entirely of mucous cells. In the reconstruction, collecting duct cells lined the proximal part of the first major secretory tubule; otherwise the junction of the two types of epithelia coincides with the point of branching.

Blood capillaries are more numerous around the collecting duct than around secretory tubules.
Secretory tubules. The secretory tubules arise directly from the collecting duct and are usually branched. At the end of each a cluster of short tubules is found. Two cell types, the mucous and serous, line the tubules (Figs 3 and 6) and are grouped together in separate parts. Mucous cells line each secretory tubule and its main branches, from the collecting duct to the distal cluster of short tubules. The latter are lined by serous cells and these cells are also found lining short tubules arising from the side of the mucous tubules. For ease of description 'mucous tubule' is used to describe the region lined with mucous cells and 'serous tubule' that lined with serous cells. In cross-section an appearance suggesting tubules containing both cell types may be seen, but reconstruction of these tubules shows that such an appearance is due to the plane of cutting through a serous tubule and its mucous tubule of origin. 
FIG. 6. Photomicrograph of a bronchial gland showing mucous (Mu.) and serous (Ser.) tubules. (Alcian blue PAS. $\times 190$.

The branches from the collecting duct are usually mucous; rarely, a serous tubule arises directly from the collecting duct. The branches do not arise regularly. In the reconstructed gland there are 13 major branches at least $50 \mu \mathrm{m}$. long and with a distinct lumen. There are also four rudimentary tubules, not included in Fig. 2, arising from the proximal end of the collecting duct. Although these measured only between 35 and 50 $\mu \mathrm{m}$. in both length and diameter, each included a proximal mucous and distal serous region. The reconstruction of two branches of the collecting duct (see Fig. 2) is illustrated in Figure 3.

Mucous tubules The mucous tubules (that is, those lined by mucous cells) invariably subdivide, in a random manner, at least once but usually more often. The tubules arising distally from the collecting duct show more complex branching than the proximal ones. The mucous tubules always terminate in serous tubules: serous tubules also arise along the course of a mucous tubule.
The mucous tubules vary in length. In the gland reconstruction the longest pathways measure up to $500 \mu \mathrm{m}$, from the collecting duct to the beginning of the terminal group of serous tubules; a mucous. side branch from a mucous tubule is usualf about $80 \mu \mathrm{m}$. long. The external diameter varies between 50 and $75 \mu \mathrm{m}$., decreasing in size distally. The mucous tubules contain only mucous cels which are columnar and 25 to $30 \mu \mathrm{m}$. in height: These cells are filled with a confluent mass of secretion that compresses the nucleus against the base of the cell. The cells stain magenta with PAS and strongly blue or blue-red with alcian bluecp PAS; with haematoxylin and eosin a basophile network is seen.

Serous tubules The majority of serous tubules are situated at the end of mucous tubules, eithe singly or in groups. Other serous tubules are foun to arise like 'buds' from the lateral wall of the mucous tubules (Fig. 3). Rarely a serous tubule arises from a collecting duct. The length of the 
serous tubules varies. Sometimes they are as short as $50 \mu \mathrm{m}$., giving the group of serous cells a spherical shape; the longest serous tubule seen in the reconstructed gland is estimated to be $\mathbf{1 8 0}$ $\mu \mathrm{m}$. The external diameter of the serous tubules is in the range of $50-70 \mu \mathrm{m}$.

The serous cells (Figs 5 and 6) are 20-30 $\mu \mathrm{m}$. in height, pyramidal in shape, with a round nucleus situated towards the base of the cell. Secretory granules are concentrated towards the cell apex and give a strong magenta staining reaction with PAS, but occasionally stain blue with alcian blue. With haematoxylin and eosin the cytoplasm is slightly eosinophilic, whereas the granules tend to be basophilic.

Serous tubules have a very small lumen which occasionally contains secretion. The lumen of a serous tubule is always continuous with the lumen of a mucous tubule.

\section{DISCUSSION}

Two types of secretory cell have long been recognized in the salivary glands (Heidenhain, 1870), and similar types have been described in the bronchial submucosal glands (Fuchs-Wolfring, 1898). While studies of the staining reactions of the human bronchial glands have been made (Burkl, 1953 ; McCarthy and Reid, 1964 ; Lamb, 1969 ; Lamb and Reid, 1969a, b), the arrangement of these secretory cells within the gland has been neglected and the presence of a functional duct system has not previously been reported.

CILIATED DUCT The epithelium lining the bronchial lumen continues into the gland. This means that ciliated epithelium lines the duct and may extend to a distance almost half a millimetre from the surface opening of the gland. It is likely that the function of surface and duct cilia is similar but it is not known whether the ciliary motion in the two regions is co-ordinated. The fluid layers covering the epithelium in large airways may be envisaged as originating from numerous points, including bronchiolo-alveolar junctions, and from within the duct of each gland. The cilia might be expected to help in the clearance of secretion from the gland duct, but the manner and rate of gland discharge is one of the many features of mucus secretion still to be elucidated. Myoepithelial cells, which presumably contribute to gland emptying, are not found in this region but occur throughout the rest of the gland.

COLLECTING DUCT In the collecting duct the cells are exceptionally tall, strongly eosinophilic and include granules, which are probably the lipochondria seen with the electron microscope. The presence of large numbers of mitochondria, shown both by special staining and with the electron microscope, as well as the uptake of glucose, indicates that these cells have a high metabolic activity. The significance of the lipochondria is not known.

Strongly eosinophilic cells with numerous mitochondria have been described in a wide variety of human tissues (Zippel, 1941). In recent years, in the parathyroid, thyroid, and salivary glands, this cell type has been called an oxyphil cell, Hürthle cell, and oncocyte, respectively (Roth, Olen, and Hansen, 1962). These cells are similar to those found in the bronchial collecting duct, except that the cells from other sites are smaller and arranged in clumps or as a follicle, but with no duct. The oxyphil cell of the parathyroid characteristically contains glycogen. A similar cell, called an oncocyte, has been reported to form tubules in the normal salivary gland (Balogh and Roth, 1965). Its relation to the duct system has not been established. It has, however, more usually been described in tumours. These cells, described as oncocytes, are smaller than the bronchial duct cells and might be expected to have a different function. In a report describing the levels of oxidative enzymes in the bronchial submucosal glands, Azzopardi and Thurlbeck (1968), without describing their distribution, report occasional groups of cells, with high enzyme activity, eosinophilic and giving no reaction with PAS. They regarded these cells as 'primitive' and included them in the category of oncocytes. The term 'oncocyte' implies a relationship between a primitive cell type and tumour formation, and we would agree with Willis (1967) that this is an unfortunate term.

It has been shown here that strongly eosinophilic cells are arranged to form a duct, an essential feature of the normal human submucosal bronchial gland. The collecting duct cell has been found to possess a high metabolic activity but shows no evidence of mucus production. Because of their position in the gland and their high activity, it is postulated that these cells have a controlling action on the ionic and water concentration of the total gland secretion. The abundant supply of blood capillaries in the region of the collecting duct further supports this hypothesis. Any changes, ionic or fluid, could be readily accomplished at this site. The concentration of ions, such as sodium and calcium, and the water content are important in determining the physical properties of bronchial secretion. All glycoproteins 
from the secretory tubules pass through part of the collecting duct to reach the bronchial lumen, although there is a wide variation in the length of duct traversed by the product of the various secretory tubules.

Certain similarities emerge between the bronchial collecting duct and the striated and intercalated ducts of the human submaxillary gland (Tandler, 1962). In both, the duct system transports glycoprotein secretion from serous and mucous tubules. The cells lining the bronchial collecting duct are tall and contain numerous mitochondria evenly distributed throughout the cytoplasm. In the cells of the salivary striated duct mitochondria are also numerous but concentrated toward the base; this is less obvious in the salivary intercalated duct cells. The salivary striated duct cell has infolding of the basal plasma membrane not found in the bronchial collecting duct cell.

THE SECRETORY TUBULES The main finding from the reconstruction of the secretory tubules is that the two cell types present are found grouped together in special regions. But while the mucous and serous cell are not mixed throughout the length of a tubule, a mucous tubule always gives rise to one or more serous tubules, if only at its most distal end. This means that serous secretion must always pass mucus-secreting cells before reaching the collecting duct. The implication of this arrangement for the mixing of the various molecular types of bronchial secretion (Lamb and Reid, 1969a, b) is not known.

The secretory tubules in cross-section are commonly described as acini. The term 'demilune' ('demilunes of Ebner-Giannuzzi', Fuchs-Wolfring, 1898) has been used to describe the groups of serous cells. This has often been taken to mean that serous cells are arranged in crescents, and flattened against a mucous tubule (e.g., Hightower, 1966). This arrangement of serous cells has not been found in the present study although such an appearance might be seen in certain planes of section. A lumen continuous with the main duct system has always been found.

GROWTH OF SUBMUCOSAL GLANDS The pattern of development by division of the serous and mucous cells within the gland is not known. While the appearance of rudimentary secretory tubules in the most proximal region of the collecting duct and complex branching tubules at the distal en suggests that new tubules form in the proxim region, the significance of the terminal position of serous tubules with respect to the mucous is not known.

We are grateful to Messrs. O. S. Tubbs, M. Panet䁬 and S. C. Lennox, surgeons of Brompton Hospita who have allowed us to study material from surgical resections; to Dr. M. E. A. Powell, from Kingsto Hospital. who has also provided us with specimensios to Mr. K. G. Moreman for the photomicrographs and to Miss Jean Waldron for the diagrams.

\section{REFERENCES}

Azzopardi, A., and Thurlbeck, W. M. (1968) Oxidative enzy pattern of the bronchial mucous glands. Amer. Rev. resp. Di 97,1038

Balogh, K., and Roth, S. I. (1965). Histochemical and electrof microscopic studies of eosinophilic granular cells (oncoyte in tumors of the parotid gland. Lab. Invest., 14, 310.

Burkl, W. (1953). Über die Sekrete in den Halbmonden der gemisc ten Drüsen des Respirationstraktes. Z. mikr.-anat. Forsch. $59,558$.

Culling, C. F. A. (1957). Handbook of Histopathological Techniqu. pp. 185 and 187-189. Butterworth, London.

Fuchs-Wolfring. S. (1898). Ueber den feineren Bau der Drüsen d Kehlkopfes und der Luftröhre. Arch. mikr. Anat., 52, 735.

Heidenhain, R. (1870). Über die acinösen Drüsen der Schleimhaute insbesondere der Nasen-Schleimhaut. H. Linder, Bresla (Inaugural Dissertation).

Hightower, N. C. (1966). Salivary secretion. In The Physiologic Basis of Medical Practice, Ed. Best, C. H., and Taylor, N. B 8th ed., p. 1061. Livingstone, Edinburgh

Lamb, D. (1969). Intracellular development and secretion of mucu in the normal and morbid bronchial tree. Ph.D. Thesis. Uno versity of London.

- and Reid, L. (1969a). Histochemical types of acid glycoprote produced by mucous cells of the tracheo-bronchial glands $\frac{\text { In }}{0}$
man. J. Path. In press.

(1969b). Histochemical types of acidic glycoproter produced by serous cells of the tracheo-bronchial glands man. In press.

McCarthy, C., and Reid, L. (1964). Intracellular mucopolysan charides in the normal human bronchial tree. Quart. J. ex. Physiol., 49, 85.

Meyrick, B., and Reid, L. (1969). In press.

Miller, W. S. (1947). The trachea and bronchi. In The Lung, 2 rid ed., p. 17. Charles C. Thomas, Springfield, Illinois.

Pelc, S. R. (1947). Autoradiograph technique. Nature (Lond.), 16 要 749.

Reid, L. (1968). Bronchial mucus production in health and diseas In The Lung, ed. Liebow, A. A., and Smith, D. E., p. 87. Willians and Wilkins, Baltimore.

Roth, S. I., Olen, E., and Hansen, L. S. (1962). The eosinophi cells of the parathyroid (oxyphil cells), salivary (onocytes) and thyroid (Hürthle cells) glands. Lab. Invest., 11, 933.

Tandler, B. (1962). Ultrastructure of the human submaxillary gland. I. Architecture and histological relationships of the secretofy cells. Amer. J. Anat., 111, 287.

Trowell, O. A. (1959). The culture of mature organs in a synthetio medium. Exp. Cell. Res., 16, 118.

Willis, R. A. (1967). Carcinomas of the salivary gland. In Pathology of Tumours, 4th ed., p. 338. Butterworths, London.

Zippel, L. (1941). Zur Kenntnis der Onkocyten. Virchows Arc path. Anat., 308, 360. 